\title{
Pemberdayaan Wirausahawan Masyarakat Tuna Karya di Desa Wisata Hanjeli Waluran Mandiri
}

\author{
Leonita Siwiyanti ${ }^{1)}$, Asep Muhamad Ramdan ${ }^{2)}$ \\ ${ }^{1,2)}$ Universitas Muhammadiyah Sukabumi \\ leony23amr@ummi.ac.id
}

\begin{abstract}
ABSTRAK : Pengangguran merupakan permasalahan yang masih belum dapat diatasi sampai saat ini di Indonesia. Berbagai Upaya untuk mengatasi permasalahan ini sudah ditempuh oleh pemerintah yang salah satunya membuka Lapangan Pekerjaan baru. KKN Kewirausahaan merupakan salah satu varian KKN yang diselenggarakan oleh LPPM Universitas Muhammadiyah Sukabumi. Program yang dilaksanakan di Desa Waluran Mandiri yaitu kewirausahaan dengn memberdayakan masyarakat tuna karya guna mengenmbangkan usaha Edu Wisata Hanjeli. Tujuan program pengabdian pada masyarakat ini adalah untuk menjawab permasalahan dan memberdayakan potensi yang ada di desa Waluran Mandiri, yaitu; melaksanakan pemetaan potensi yang mendukung produk pariwisata, menumbuhkan minat serta keterampilan berwirausaha masyarakat tuna karya dan menginisiasi Usaha Rintisan Masyarakat Tuna Karya (URIMASTU). Kegiatan yang dilaksanakan pada pengabdian masyarakat dengan melibatkan mahasiswa KKN adalah 1) melaksanakan Kegiatan Pendataan dan Pemetaan Potensi Desa; 2) melaksanakan Sosialisasi Program KKN dan FGD; 3) membentuk kelompok kerja usaha dan pelatihan Kewirausahaan; dan 4) merintis usaha Edu Wisata Hanjeli. Berdasarkan hasil dari kegiatan pengabdian pada masyarakat maka melalui program usaha Edu Wisata Hanjeli yang mengembangkan keahlian para warga masyarakat dengan mengelola sumber daya alam yang sangat berpotensi untuk mensejahterakan warganya.
\end{abstract}

Kata Kunci : Wirausaha, Tuna Karya, Wisata Hanjeli

ABSTRACT : Unemployment is a problem that has still not been resolved in Indonesia. To overcome this problem, the government has done some efforts such as opening new jobs. Entrepreneurship Community Service (Kuliah Kerja Nyata) is one of the community service variants organized by LPPM University of Muhammadiyah Sukabumi. The program carried out in Waluran Mandiri Village. The entrepreneurship program was conducted by empowering the disabled people to develop the Hanjeli Tourism Edu business. The purpose of this community service program is to answer problems and empower the potential that exists in the Waluran Mandiri Village, namely; carry out mapping of potentials that support tourism products, foster interest and entrepreneurial skills of people with disabilities and initiate Usaha Rintisan Masyarakat Tuna Karya (URIMASTU). Activities carried out in community service involving community services students are 1). Carry out Village Potential Mapping and Data Collection Activities; 2). implement the Community Service Program and FGD Socialization; 3). establish business workgroups and entrepreneurship training; and 4). started the Hanjeli Tourism Edu business. Based on the results of community service activities, through the Hanjeli Tourism Edu business program that develops the expertise of community members by managing natural resources that have the potential to prosper for its citizens.

Keywords : Entrepreneurship, unemployment, Hanjeli Tourism

\section{PENDAHULUAN}

Pengangguran merupakan permasalahan yang masih belum dapat diatasi sampai saat ini di Indonesia (Prevention, Taruna, \& Taruna, 2007). Berbagai Upaya untuk mengatasi permasalahan ini sudah ditempuh oleh pemerintah seperti membuka 
Lapangan Pekerjaan baru, memperbaiki kondisi ekonomi makro, pengurangan pajak upah (Karyaone, 2019), namun belum mampu mengatasi pengangguran di Indonesia.

Masalah pengangguran ini sangat penting untuk diperhatikan karena pengangguran itu sangat berpontensi menimbulkan kerawanan berbagai kriminal dan gejolak sosial, politik dan kemiskinan. Selain itu, pengangguran juga merupakan pemborosan yang luar biasa. Setiap orang harus mengkonsumsi beras, gula, minyak, pakaian, energi listrik, sepatu, jasa dan sebagainya setiap hari, tapi mereka tidak mempunyai penghasilan (Widodo \& Nugroho, 2014). Berdasarkan data Badan Pusat Statistik jumlah pengangguran terbuka 2018 sebanyak 7 juta jiwa atau 5,34\% dari total angkatan kerja sebanyak 131 juta jiwa. Tingkat hal ini jelas berdampak pada tingkat kemiskinan di Indonesia (BPS, 2018).

Jawa Barat secara geografis memiliki jarak yang relative dekat dengan pusat Pemerintahan Republik Indonesia memiliki persoalan yang sama berkaitan dengan pengangguran, Dinas Tenaga Kerja dan Transmigrasi Jawa Barat menargetkan angka pengangguran di Jawa Barat menyentuh angka 7 persen dari jumlah angkatan kerja di Jabar pada 2023. Saat ini, di Jabar angka pengangguran terbuka mencapai 8 persen lebih atau 1,85 juta jiwa. Upaya tersebut akan dimulai pada tahun 2019 ini dengan penurunan di angka 7,9 persen dari jumlah angkatan kerja di Jabar yang mencapai 22,63 juta jiwa (Nurulliah, 2019).

Kabupaten Sukabumi merupakan kabupaten yang memiliki garis pantai terpanjang kedua se Jawa-Bali memiliki 47 Kecamatan dengan jumlah penduduk 2.453.498 jiwa yang terdiri atas 1.243.192 jiwa penduduk laki-laki dan 1.210.306 jiwa penduduk perempuan. Jumlah pengangguran angkatan kerja usia produktif di masih tergolong tinggi, diperkirakan masih ada 24 persen atau sekitar 414.831 orang masih belum beroleh pekerjaan, dari jumlah tersebut diperkirakan 123.171 orang hanya menyelesaikan pendidikan di tingkat sekolah dasar (SD). Sementara 191.334 orang hanya bersekolah sampai sekolah menengah pertama (SMP), sehingga mereka sulit untuk menemukan pekerjaan yang layak. Perluasan kesempatan kerja dan kesempatan usaha merupakan salah satu agenda prioritas pembangunan Kabupaten Sukabumi (Badan Pusat Statistik, 2018).

Kuliah Kerja Nyata $(\mathrm{KKN})$ merupakan salah satu perwujudan dari Tri Dharma Perguruan Tinggi yaitu pengabdian masyarakat. Pengabdian merupakan suatu wujud kristalisasi dan integralisasi dari ilmu yang tertuang secara teoritis di bangku kuliah untuk diterapkan secara nyata dalam kehidupan sehari-hari di masyarakat, sehingga ilmu yang diperoleh dapat diaplikasikan dan dikembangkan dalam kehidupan masyarakat luas. KKN bagi mahasiswa diharapkan dapat menjadi suatu pengalaman belajar yang baru untuk menambah pengetahuan, kemampuan, dan kesadaran hidup bermasyarakat. Bagi masyarakat, kehadiran mahasiswa diharapkan mampu memberikan motivasi dan inovasi dalam bidang sosial kemasyarakatan. 
KKN Kewirausahaan merupakan salah satu varian KKN yang diselenggarakan oleh LPPM Universitas Muhammadiyah Sukabumi dengan tujuan membentuk, membina dan mengembangkan kewirausahaan secara sistematis. Hal ini sebagai wujud sinergitas Universitas Muhammadiyah Sukabumi dengan Pemerintah Kabupaten Sukabumi dalam penanganan Masalah pengangguran khususnya di perdesaan. Program yang dilaksanakan di Desa Waluran Mandiri yaitu kewirausahaan di bidang Edu Wisata Hanjeli. Program ini disesuaikan dengan potensi desa dalam bidang kuliner dan aset bumi pariwisata berupa Hanjeli. Potensi tersebut perlu dikembangkan demi kelangsungan potensi yang semakin luas.

\section{PERMASALAHAN}

Berdasarkan latar belakang masalah di atas, maka dapat dirumuskan beberapa permasalahan antara lain, 1) mempetakan potensi yang mendukung produk pariwisata di desa Waluran Mandiri, 2) cara menumbuhkan minat serta keterampilan berwirausaha bagi masyarakat tuna karya di desa Waluran Mandiri, 3) pemberdayaan masyarakat tuna karya dalam menginisiasi sebuah usaha rintisan di desa Waluran Mandiri.

\section{METODE PELAKSANAAN}

Pelaksanaan kegiatan pengabdian pada masyarakat perlu adanya persiapanpersiapan yang harus dipenuhi agar kegiatan tersebut dapat berjalan dengan baik. Persiapan yang dilakukan adalah sebagai berikut.

1. Pendataan tuna karya dan menganalisis potensi desa Waluran Mandiri.

2. Sosialisasi Program KKN dan FGD.

3. Membentuk kelompok kerja usaha dari data tuna karya dan melaksanakan pelatihan kewirausahaan.

4. Menentukan rintisan usaha di desa Waluran Mandiri.

Berdasarkan hasil identifikasi pertama yang di dapat mengenai keadaan potensi Desa Wisata Hanjeli. Di Desa Waluran Mandiri terdapat berbagai potensi masyarakat di bidang pengolahan pangan, pertanian, kerajinan dan lain sebagainya. Namun, kurangnya minat warga untuk berwirausaha sehingga potensi yang sudah ada sulit untuk dikembangkan.

Gambaran umum kondisi desa Waluran Mandiri adalah sebagai berikut.

1. Letak desa waluran Mandiri berada di sebelah timur dari pusat kecamatan berjarak dengan luas wilayah 2.114 Ha. terdiri dari luas Daratan sebanyak 1.414 Ha, dan lahan basah seluas 700 Ha. Topografi Desa Waluran Mandiri termasuk dalam kategori daerah daratan rendah dan ketinggian kurang lebih 400 meter dari permukaan laut (DPL)

2. Adapun batas-batas wilayah Desa Waluran Mandiri kecamatan waluran Kabupaten Sukabumi adalah sebagai berikut :

a. Sebelah utara : Desa Kertajaya Kec. Simpenan 
b. Sebelah Timur : Desa Mangunjaya Kec. Waluran

c. Sebelah Selatan : Desa Waluran Kec. Waluran

d. Sebelah Barat : Desa Mekar jaya Kec. Ciemas

3. Adapun luas wilayah Desa Waluran Mandiri adalah 2.114 Ha yang terdiri dari :

a. Tanah Sawah : 700 Ha dimana tanah tersebut terdiri dari irigasi setengah teknis seluas $320 \mathrm{Ha}$ dan tadah Hujan seluas $380 \mathrm{Ha}$

b. Tanah Darat : $1.414 \mathrm{Ha}$ dimana tanah tersebut terdiri dari pekarangan seluas/ bangunan seluas $50 \mathrm{Ha}$, Tegalan seluas $1.294 \mathrm{Ha}$, dan lain-lain seperti sungai, jalan, dan pemakaman seluas $70 \mathrm{Ha}$.

Setelah melihat gambaran umum dari wiilayah desa tersebut, maka langkah awal yang dilakukan yaitu dengan mendata masyarakat tuna karya yang belum memiliki pekerjaan tetap. Pendataan dilakukan dengan mendatangi rumah-rumah masyarakat tuna karya, data hasil pendataan tersebut direkap kembali untuk diproses menjadi sasaran dalam pelatihan. Selain pendataan masyarakat tuna karya, program yang kami lakukan ialah melakukan diskusi dengan masyarakat Desa Waluran Mandiri untuk mengetahui permasalahan dan kebutuhan masyarakat tersebut.

Agar dapat merealisasikan tujuan dan sasaran dari pendataan masyarakat tuna karya tersebut, maka mahasiswa melakukan pendekatan dengan mendatangi rumah ketua RT khususnya di kedusunan II Waluran yang diambil sebanyak 6 RT termasuk RT yang berada di lokasi posko mahasiswa. Cara yang dilakukan mahasiswa dalam mendata yaitu dengan membagikan formulir Tuna karya kepada masyarakat yang tidak memiliki pekerjaan tetap dan remaja yang putus sekolah. Sesudah mendapatkan hasil dari pendataan tuna karya tersebut, maka selanjutnya dilakukan penginputan data tuna karya yang sudah terkumpul sebagai sasaran untuk melihat potensi masyarakat guna berwirausaha.

Potensi desa dalam pelaksanaan program KKN sebelumnya kami analisis dengan menggunakan analisis SWOT. Berikut adalah analisis SWOT potensi Desa Waluran Mandiri.

Tabel 1. Analisis SWOT Potensi Desa Waluran Mandiri

\begin{tabular}{clcccc}
\hline No & Potensi Desa & Kekuatan & Kelemahan & Peluang & Ancaman \\
\hline 1 & $\begin{array}{l}\text { Penduduk/Su } \\
\text { mber Daya } \\
\text { Manusia }\end{array}$ & $\begin{array}{c}\text { Banyaknya } \\
\text { SDM yang } \\
\text { produktif }\end{array}$ & $\begin{array}{c}\text { Banyaknya } \\
\text { yang putus } \\
\text { sekolah }\end{array}$ & $\begin{array}{c}\text { Memiliki potensi } \\
\text { alam yang melimpah } \\
\text { yang bisa dikelola } \\
\text { oleh sumber daya } \\
\text { yang ada }\end{array}$ & $\begin{array}{c}\text { Kurangnya } \\
\text { pengetahuan } \\
\text { tentang } \\
\text { kewirausahaan }\end{array}$ \\
\hline 2 & $\begin{array}{l}\text { Potensi Alam } \\
\text { (hanjeli) }\end{array}$ & $\begin{array}{c}\text { Banyaknya } \\
\text { potensi alam } \\
\text { yang dapat } \\
\text { dijadikan } \\
\text { prodak yang } \\
\text { bervariasi }\end{array}$ & $\begin{array}{c}\text { Hanjeli } \\
\text { hanya bisa } \\
\text { ditanam } \\
\text { pada musim } \\
\text { hujan }\end{array}$ & $\begin{array}{c}\text { Bisa dikembangkan } \\
\text { dengan bekerjasama } \\
\text { para akademisi } \\
\text { sehingga hanjeli } \\
\text { dapat ditanam tidak } \\
\text { pada musim hujan }\end{array}$ & $\begin{array}{c}\text { Pengolahan } \\
\text { tidak dapat } \\
\text { dilakukan secara } \\
\text { terus menerus, } \\
\text { harus menunggu } \\
\text { musim hujan }\end{array}$ \\
\hline 3 & Potensi & Banyaknya & Hanya & Bisa dijual tidak & Masih asingnya \\
\hline
\end{tabular}




\begin{tabular}{cccccc}
\hline No & Potensi Desa & Kekuatan & Kelemahan & Peluang & Ancaman \\
\hline & Produk & produk & orang-orang & hanya local tetapi & rasa dari produk \\
& hanjeli yang & tertentu & bisa go internasional \\
dapat & yang bisa & & memalidiki \\
& dijadikan & mengolah & & pelanggan yang \\
& berbagai & dan & & \\
& produk dari & menangani & & \\
& bahan baku & hanjeli & & \\
& yang sama & dengan baik & & \\
& & &
\end{tabular}

\section{PELAKSANAAN}

Kegiatan sosialisasi dimulai pada tanggal 25 Juli 2019, terlebih dahulu dengan mengunjungi Ketua RT yang ada di Desa Waluran Mandiri. Sosialisasi yang kami sampaikan mengenai program KKN Tematik UMMI 2019 yaitu mengenai Usaha Rintisan Masyarakat Tuna Karya yang dilaksanakan di Desa Waluran Mandiri. Sosialisasi selanjutnya yaitu, kelompok kami mengunjungi Rumah Baca Sauyunan untuk memperkenalkan diri kepada pemuda-pemuda yang ada disekitar untuk berkenalan dan berdiskusi serta menyampaikan tujuan dan Program mengenai Usaha Rintisan Masyarakat Tuna Karya. Dan kami juga meminta izin untuk ikut berpartisipasi membantu pihak Saung Pintar dalam mengajarkan anak-anak Desa waluran Mandiri di Rumah Baca Sauyunan.
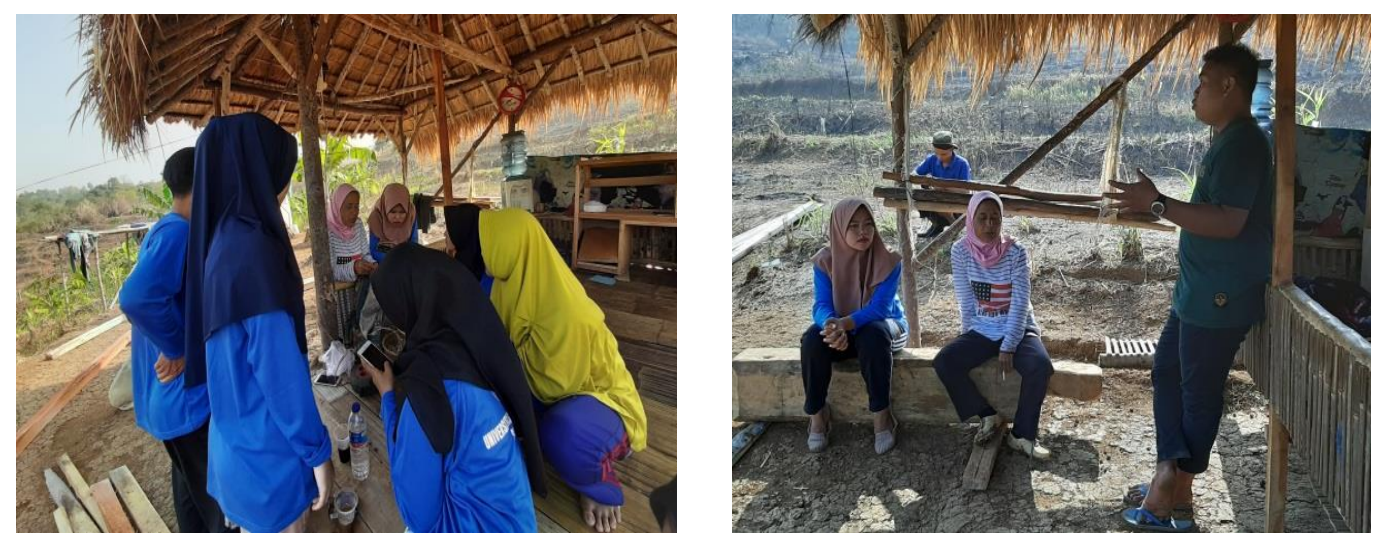

Gambar 1. Sosialisasi kepada warga masyarakat

Sosialisasi selanjutnya kelompok kami mengikuti pengajian putri rutinan, sekaligus memperkenalkan serta menyampaikan tujuan dan Program Usaha Rintisan Masyarakat Tuna Karya. Pada tanggal 29 Juli 2019, kelompok kami melaksanakan sosialisasi kepada pihak Desa, Khususnya Sekretaris Desa. Sosialisasi yang kami sampaikan yaitu mengenai KKN Tematik UMMI 2019 Program URIMASTU dan pelaksanaan Lokakarya Awal. 
Lokakarya Awal dilaksanakan pada tanggal 01 Agustus 2019, Sosialisasi yang kami sampaikan adalah program KKN Tematik UMMI 2019 yaitu mengenai Usaha Rintisan Masyarakat Tuna Karya yang dilaksanakan di Aula Desa Waluran Mandiri. Program yang direncanakan yaitu Desa Wisata Hanjeli dan Literasi Budaya serta beberapa program sekunder sesuai kebutuhan masyarakat.
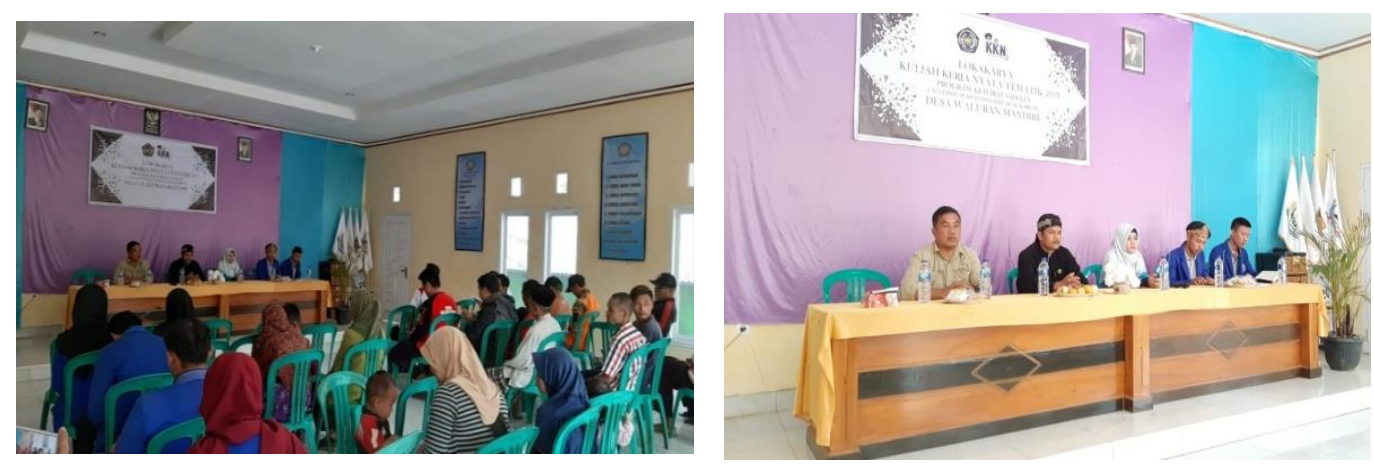

Gambar 2. Kegiatan Lokakarya Awal

FGD dilakukan setelah selesai melaksanakan sosialisasi kepada masyarakat dan memaparkan program pada kegiatan Lokakarya Awal, yang mana kegiatan ini membahas segala permasalahan desa Waluran Mandiri serta kegiatan yang dapat dilakukan oleh peserta KKN di Desa Waluran Mandiri. Focus Group Disscussion dilakukan sebagai langkah awal dalam proses pemaparan identifikasi potensi dan sasaran juga membangun komitmen dengan masyarakat mengenai apa yang akan dilakukan dan tidak dilakukan selama KKN (Ramdan, 2019).

Pembahasan dalam FGD tersebut mendapatkan beberapa hasil permasalahan di Desa Waluran Mandiri khususnya domisili peserta KKN tinggal. Masyarakat mempunyai permasalahan dalam mendapatkan pekerjaan, permasalahan tersebut terjadi karena pemerintah lebih mendahulukan masyarakat diluar Desa Waluran Mandiri untuk mengembangkan desanya. Sehingga hasil dari FGD ini memunculkan solusi dari masalah-masalah diatas, yaitu dengan membuat kelompok kerja usaha yang akan mengembangkan potensi alam dari desa Waluran Mandiri dan memperkuat dengan melakukan pelatihan kewirausahaan. 


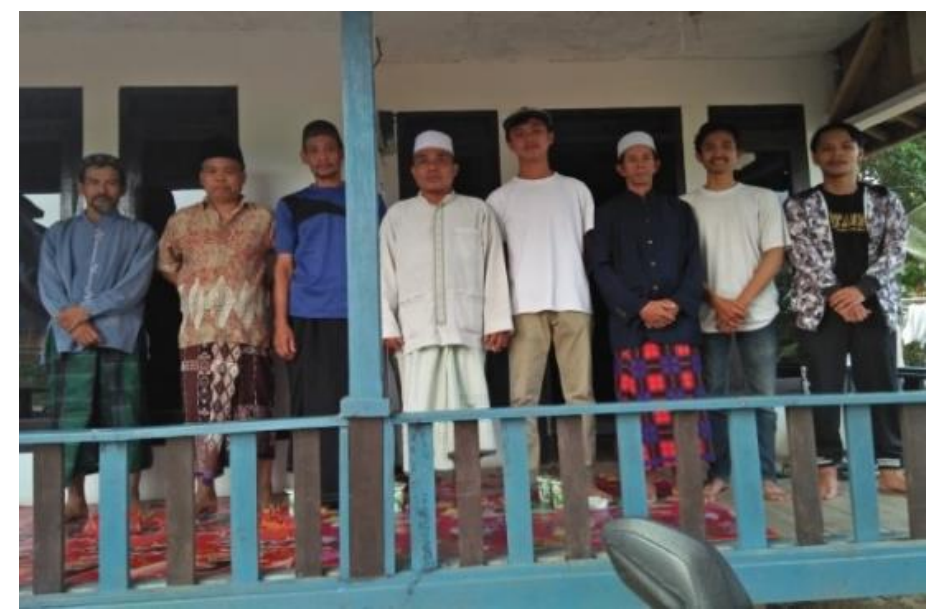

Gambar 3. FGD dengan Warga Masyarakat

\section{HASIL DAN LUARAN}

\section{Membentuk Kelompok Kerja Usaha Dan Pelatihan Kewirausahaan}

\section{Pembentukan kelompok kerja usaha}

Dalam membentuk kelompok kerja usaha ini tidak dilakukan secara ke seluruhan, hal ini dikarenakan sudah terbentuk kelompok kerja Desa Wisata Hanjeli. Kelompok kerja ini sudah berjalan, namun masih kurang optimal dalam pelaksanaannya. Oleh sebab itu, langkah awal yang dilakukan yaitu dengan mengajukan Surat Keputusan kepada pihak desa untuk dapat melegalkan pengurus Desa Wisata Hanjeli. Dimana susunan pengurusnya adalah sebagai berikut.
a. Ketua
: Asep Hidayat
b. Sekretaris
: Rahma Yusuf
c. Bendahara
: Sumyati
d. Divisi Pertanian
: Koyah
e. Divisi Olahan Pangan
: Denie Ramadhan
f. Divisi Pengemasan
: Wati
g. Divisi Pemasaran
: Herman
h. Divisi Dokumentasi
: Yusuf Andes 

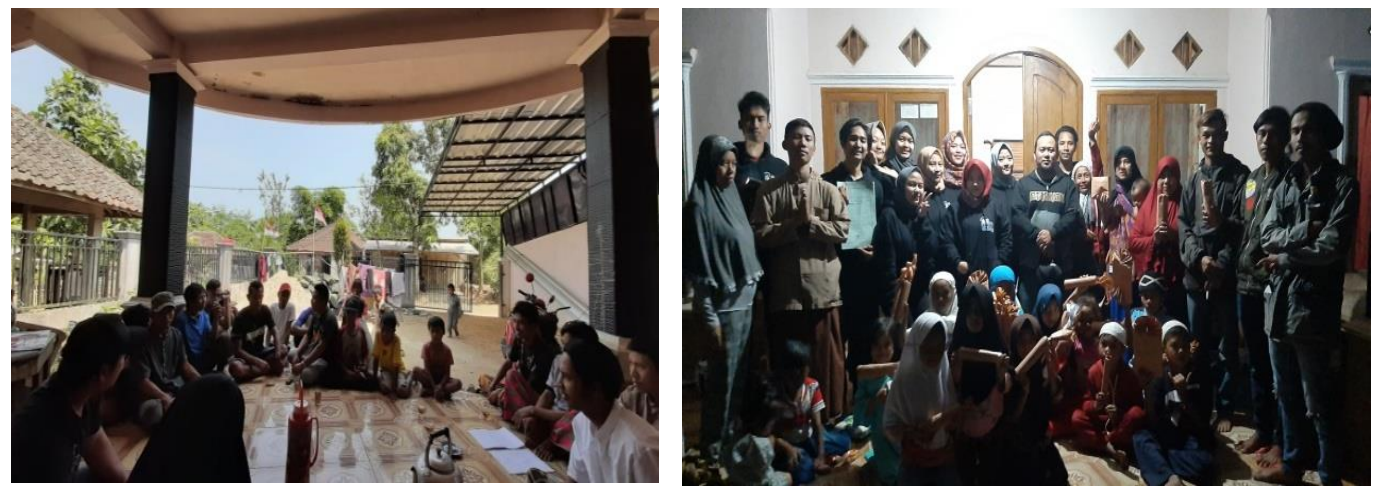

Gambar 4. Kelompok Kerja Usaha

\section{Pelatihan Kewirausahaan dan Edu Wisata}

Selanjutnya sesudah dibentuknya kelompok kerja usaha maka dilaksanakanlah sebuah pelatihan Kewirausahaan dan Edu Wisata di Desa Waluran Mandiri. Tujuan dari pelatihan ini adalah untuk memberikan pelatihan dasar kewirausahaan bagi seluruh peserta khusunya pengurus Desa Wisata Hanjeli untuk mengetahui pengertian, keuntungan, teknik dasar, dan cara mengembangkan usaha yang akan di terapkan di Desa Wisata Hanjeli yaitu Edu Wisata. Selain itu, dapat menumbuhkan minat peserta dalam mengembangkan potensi-potensi yang terdapat di Desa Waluran Mandiri.
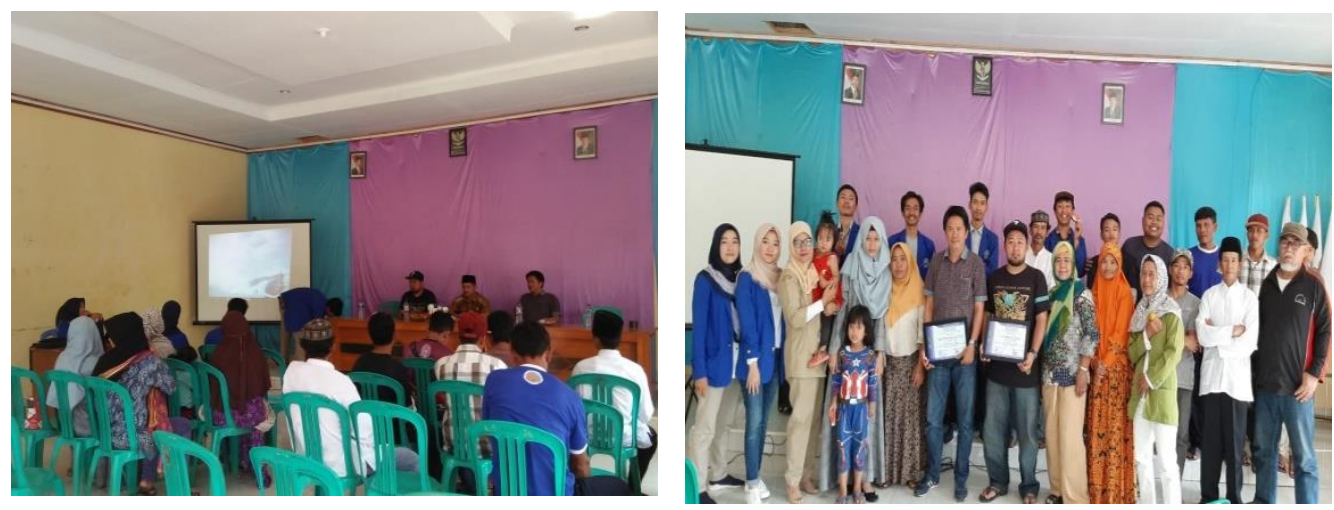

Gambar 5. Pelatihan Kewirausahaan dan Edu Wisata Hanjeli

Waktu Pelaksanaan program ini pada tanggal 27 Agustus 2019 kembali berkolaborasi dengan seluruh Kelompok KKN Tematik 2019 yang ada di Desa Waluran Mandiri. Kegiatan ini bertempat di Aula Desa Waluran Mandiri pada pukul 13.00 WIB s/d selesai. Kegiatan ini dihadiri pula oleh bapak Kepala Desa dan seluruh staff jajarannya, masyarakat tuna karya khususnya pengurus Desa Wisata Hanjeli. Hasil dari program ini ialah berwirausaha yaitu seseorang yang mempunyai kemampuan melihat peluang bernilai uang dengan cara menambah inovasi. 


\section{Menentukan Rintisan Usaha di desa Waluran Mandiri}

\section{Merintis Usaha Edu Wisata di Desa Wisata Hanjeli}

Pelaksanaan kegiatan ini dilakukan dengan melaksanakan praktik beberapa pengolahan pangan hanjeli dan membuat saung sehat (program sekunder). Terdapat beberapa produk penunjang Desa Wisata Hanjeli sebagai rintisan usaha Edu Wisata Hanjeli yang akan dijadikan usaha bagi masyarakat desa Waluran Mandiri, antara lain.

\section{a. Situ Endah Cekdam}

Pada tahun 1987 Situ Cekdam sudah terbentuk namun ukuran serta bentuknya memang tidak merata. Sumber mata air yang memenuhi Situ Cekdam berasal dari gunung Waluran dan gunung Bentang. Perkembangan Situ Cekdam mulai pesat dari waktu ke waktu hingga ada bantuan dari pihak pemerintah sehingga Situ Cekdam kemudian diperindah kembali dengan cara diberi dinding tembok sebagai penambah pesona Situ Cekdam itu sendiri.

Pihak pemerintah desa mencanangkan agar situ cekdam dijadikan sebuah destinasi wisata namun sampai saat ini hal tersebut masih belum terealisasi dikarenakan banyak faktor-faktor yang mempengaruhinya sehingga Situ Cekdam hanya dijadikan sebagai sistem irigasi dan belum dikelola secara baik menjadi tempat pariwisata namun warga setempat kini mulai berinisiatif membangun tempat-tempat untuk santai para pengunjung, namun belum dikelola secara utuh sampai saat ini.

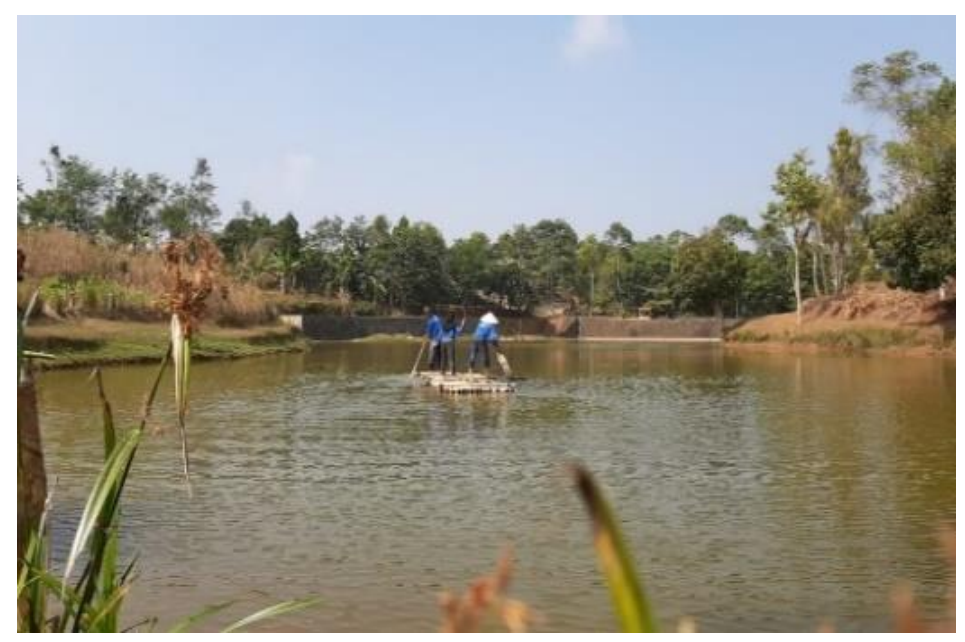

\section{Gambar 6. Situ Cekdam/Situ Endah Waluran Mandiri}

\section{b. Permainan Tradisional Desa Waluran Mandiri}

Permainan tradisional merupakan permainan yang dimainkan oleh anak-anak pada suatu daerah secara tradisi. Tradisi dalam hal ini ialah permainan tersebut telah diwarisi dari generasi yang satu ke generasi berikutnya. Permainan yang dimainkan oleh anak-anak desa Waluran Mandiri adalah permainan Egrang dan Sondah/Engklek. Permainan ini dilakukan berramai-ramai dalam sebuah kelompok anak-anak, dan 
mereka sudah terbiasa melakukannya. Permainan yang sangat sederhana dari bambu dan peralatan yang sederhanan juga.

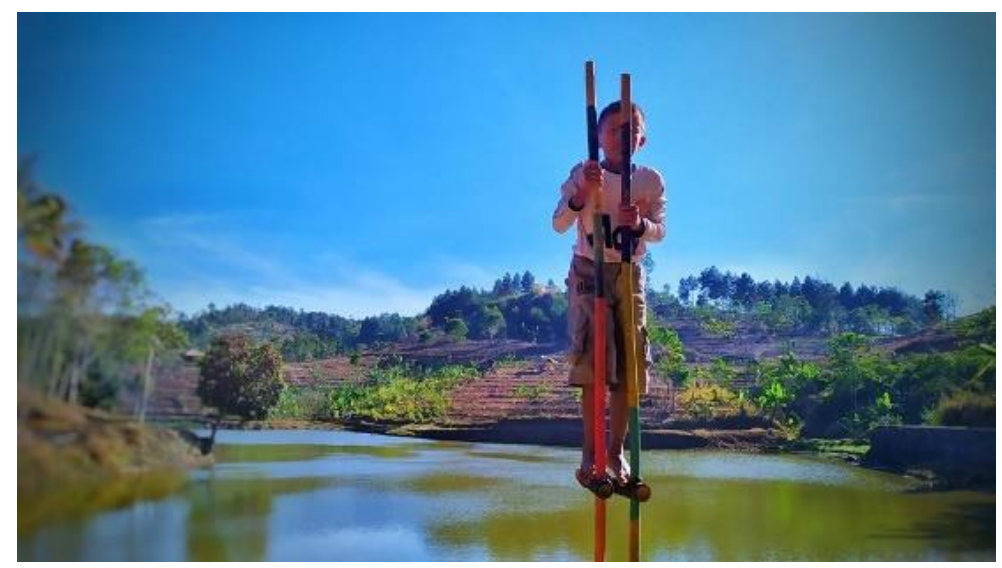

\section{Gambar 7. Permainan Tradisional Waluran Mandiri}

\section{c. Produk Olahan Hanjeli}

Hanjeli memiliki karakteristik yang hampir sama seperti beras baik dalam kandungan gizi maupun karakteristik fisiknya. Oleh sebab itu, Hanjeli bisa di olah menjadi berbagai olahan pangan. Di Desa Wisata Hajeli ini Hanjeli di Olah menjadi beberapa makanan seperti Rengginang, Peuyeum Hanjeli, Wajit/Dodol Hanjeli, Kerupuk Hanjeli dan Teng-teng Hanjeli.

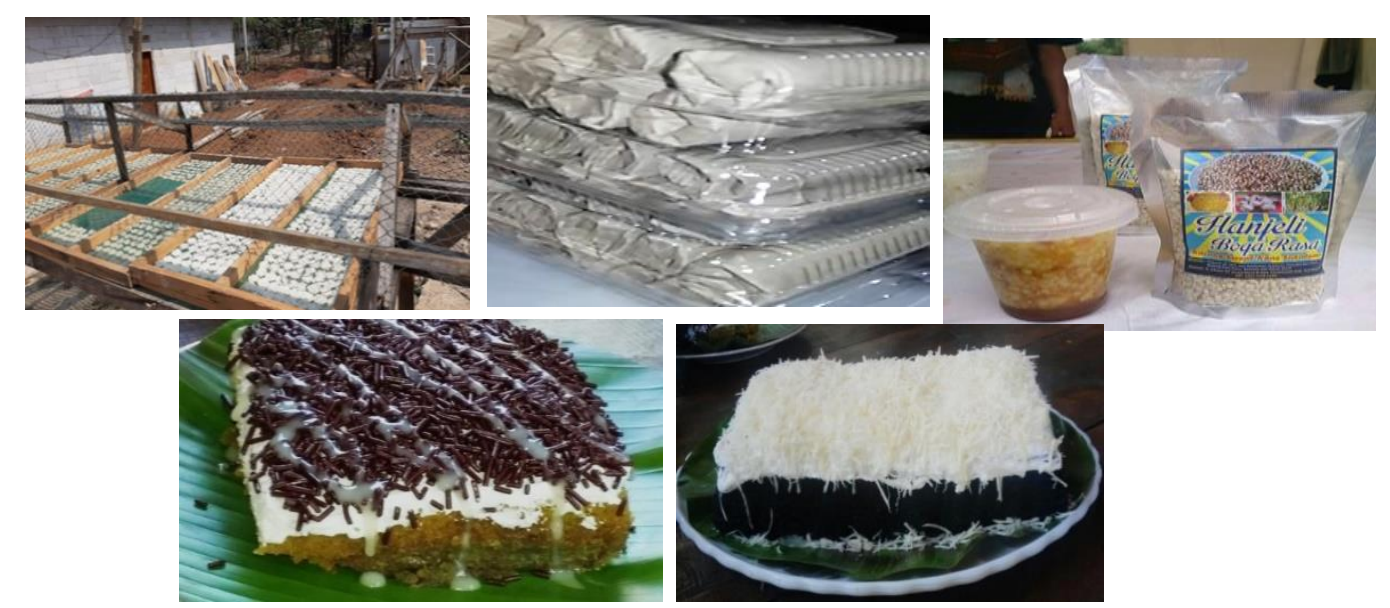

Gambar 8. Produk Olahan Rengginang, Dodol, Bubur, Bolu dan Brownies Hanjeli

Berdasarkan berbagai macam produk olahan Hanjeli di atas, maka dapat dilihat hasil analisis SWOT keseluruhan produk-produk tersebut, dan disajikan dalam Tabel 2. 
Tabel 2. Analisis SWOT Produk Olahan Hanjeli

\begin{tabular}{|c|c|c|c|c|c|}
\hline No & Produk & Kekuatan & Kelemahan & Peluang & Hambatan \\
\hline 1 & $\begin{array}{c}\text { Ranginang } \\
\text { Hanjeli }\end{array}$ & $\begin{array}{c}\text { Berbeda dari } \\
\text { raginang biasanya } \\
\text { karena dibuat dari } \\
\text { henjeli langsung, } \\
\text { hanjeli memiliki } \\
\text { banyak manfaat } \\
\text { untuk tubuh }\end{array}$ & $\begin{array}{l}\text { Kurangnya varian } \\
\text { rasa yang di } \\
\text { berikan, mudah } \\
\text { ditiru oleh } \\
\text { pedagang lain, } \\
\text { sulitnya mencari } \\
\text { bahan baku ketika } \\
\text { hanjeli tidak } \\
\text { panen }\end{array}$ & $\begin{array}{l}\text { Belum ada } \\
\text { yang } \\
\text { membuat } \\
\text { ranginang } \\
\text { berbahan } \\
\text { dasar hanjel }\end{array}$ & $\begin{array}{l}\text { Mudah ditiru } \\
\text { oleh para } \\
\text { pedagang lain, } \\
\text { sulitnya mencari } \\
\text { bahan baku } \\
\text { ketika hanjeli } \\
\text { tidak panen }\end{array}$ \\
\hline 2 & $\begin{array}{l}\text { Dodol } \\
\text { Hanjeli }\end{array}$ & $\begin{array}{l}\text { Tanpa bahan } \\
\text { pengawet, terbuat } \\
\text { dari bahan baku } \\
\text { yang khusus }\end{array}$ & $\begin{array}{l}\text { Tidak tahan lama, } \\
\text { tmudah ditiru } \\
\text { oleh orang lain, } \\
\text { kurangnya varian } \\
\text { rasa }\end{array}$ & $\begin{array}{c}\text { Bisa menarik } \\
\text { minat para } \\
\text { konsumen }\end{array}$ & $\begin{array}{c}\text { Sulitnya } \\
\text { mencari bahan } \\
\text { baku hanjeli, } \\
\text { kemasan kurang } \\
\text { bagus, sulitnya } \\
\text { mencari bahan } \\
\text { baku ketika } \\
\text { hanjeli tidak } \\
\text { panen, }\end{array}$ \\
\hline 3 & $\begin{array}{l}\text { Brownis } \\
\text { dan bolu } \\
\text { Hanjeli }\end{array}$ & $\begin{array}{l}\text { Memiliki bahan } \\
\text { baku yang khusus } \\
\text { serta manfaay } \\
\text { dari hamjeli } \\
\text { sendiri untuk } \\
\text { kesehatan tubuh }\end{array}$ & $\begin{array}{l}\text { Kemasan yang } \\
\text { belum optimal } \\
\text { dan rasa yang } \\
\text { tidak jauh } \\
\text { berbeda dengan } \\
\text { brownis pada } \\
\text { umumnya }\end{array}$ & $\begin{array}{l}\text { Bisa ikut } \\
\text { bersaing di } \\
\text { pasaran }\end{array}$ & $\begin{array}{c}\text { Sulitnya } \\
\text { mencari bahan } \\
\text { baku utama } \\
\text { hanjeli jika } \\
\text { sedang tidak } \\
\text { panen }\end{array}$ \\
\hline 4 & $\begin{array}{l}\text { Bubur } \\
\text { Hanjeli }\end{array}$ & $\begin{array}{c}\text { Memilikirasa } \\
\text { yang khas serta } \\
\text { berbeda dari } \\
\text { bubur lainnya }\end{array}$ & $\begin{array}{l}\text { Tidak than lama, } \\
\text { dan sulitnya } \\
\text { mencari bahan } \\
\text { baku ketika } \\
\text { hanjeli tidak } \\
\text { panen }\end{array}$ & $\begin{array}{c}\text { Bisa menarik } \\
\text { minat para } \\
\text { konsumen }\end{array}$ & $\begin{array}{c}\text { Sulitnya } \\
\text { mengenalkan } \\
\text { bubur hanjeli } \\
\text { dikalangan } \\
\text { masyarakat, }\end{array}$ \\
\hline
\end{tabular}

\section{d. Sajian Desa Wisata Hanjeli}

1) Penyambutan menggunakan tarian

Setiap wisatawan yang mengunjungi Desa Wisata Hanjeli pada saat keadatangan nya akan disambut oleh tarian Merak khas desa Wisata Hanjeli yang di persembahkan oleh anak-anak yang ada di Desa Wisata Hanjeli.

2) Nganjang Ka Sawah

Nganjang ka sawah adalah sebuah konsep yang dikembangkan sebagai bagian dari eduwisata Hanjeli dicanangkan akan menarik minat para pengunjung. Pada saat ini para ibu-ibu atau anak muda lebih sering berkunjung ke tempat-tempat ramai seperti pusat perbelanjaan, pusat hiburan dan tempat ramai yang modern serta bagus untuk dijadikan spot foto, dan 
kebanyakan dari para ibu-ibu tersebut sudah lupa terhadap tempat pembudidayaan tanaman. Dari sinilah konsep nganjang ka sawah terbentuk. Dengan adanya desa wisata Hanjeli diharapkan para pengunjung ibu-ibu dapat kembali ingat dengan adat atau kebiasaan pergi ke sawah. pengunjung selain diarahkan melihat proses pembudidayaan hanjeli pengunjung juga disajikan dengan nuansa alam yang indah dan tenang seperti hamparan persawahan yang indah dimana tempat tersebut nantinya akan digunakan sebagai tempat makan bersama/ngaliwet bareng.

3) Hiburan

Saat berkunjung ke Desa Wisata Hanjeli peengunjung akan disajikan oleh hiburan berupa pentas pencak silat yang disajikan oleh klub atau padepokan pencak silat yang ada di Desa Wisata Hanjeli. Waktu untuk penyajian hiburan ini pada malam hari.

4) Homestay

Homestay adalah rumah yang disewakan kepada tamu dalam jangka waktu tertentu untuk mempelajari budaya setempat atau rutinitas tertentu dalam suatu wilayah, homestay yang berdiri di desa wisata hanjeli masih mengelola rumah-rumah warga setempat. Hal tersebut dikarenakan warga setempat masih menjunjung tinggi adat istiadat yang ada di desa Wisata Hanjeli, sehingga para pengujung bisa menikmati kebudayaan Desa wisata Hanjeli melalui warga setempat dengan menginap di homestay. Contoh warga Desa Wisata Hanjeli biasanya setiap pagi membuat bubuy singkong dan banyak kegaiatan lainnya.

\section{e. Proses Pemasaran Desa Wisata Hanjeli}

Desa wisata Hanjeli dipasarkan dengan berbagai cara, salah satu media yang digunakan untuk memasarkan Desa Wisata Hanjeli yaitu dengan menggunakan media online seperti Facebook, Instagram dan Youtube. Produk olahan hanjeli bisa ditemukan di Desa Wisata Hanjeli, Gerai DESKRANSDA Kabupaten Sukabumi, dan Café Lets Coffee Surade Sukabumi. Salah satu cara pemasaran yang dilakukan oleh kelompok kerja dibantu mahasiswa KKN UMMI yaitu dengan membuat website Edu Wisata Hanjeli (Waluran Mandiri). 


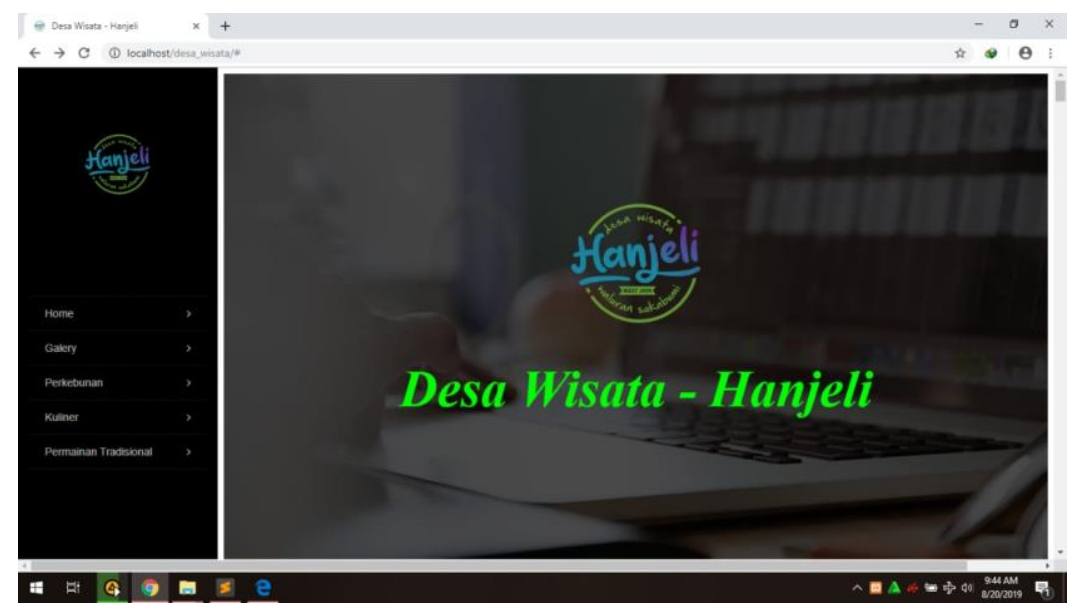

Gambar 9. Pembuatan Website Desa Wisata Hanjeli

\section{Pembuatan Buku Desa Wisata Hanjeli}

Penyusunan buku ini mahasiswa melakukan wawancara kepada beberapa tokoh masyarakat di Desa Waluran Mandiri seperti, Bapak Asep Hidayat sebagai pelopor Desa Wisata Hanjeli, Ibu Koyah sebagai Ketua Kelompok Wanita Tani (KWT), Pak Entis dan Ki Pudin sebagai narasumber mengenai Situ Endah Cekdam, Pak Yunus dan Pak Udil sebagai salah satu perintis jurus simpay pajampangan sekaligus Ketua IPSI (Ikatan Pencak Silat Indonesia) Desa Waluran Mandiri dan pelatih pencak silat.

Selain itu berdasarkan hasil wawancara dengan berbagai tokoh masyarakat di Desa Waluran Mandiri dapat disimpulkan bahwa Desa Wisata Hanjeli adalah kawasan atau sebuah lingkungan pedesaan yang memiliki daya tarik berupa pembudidayaan hanjeli sebagai kearifan lokal dan adat istiadat yang memiliki keunikan dan keaslian ciri khas suasana.

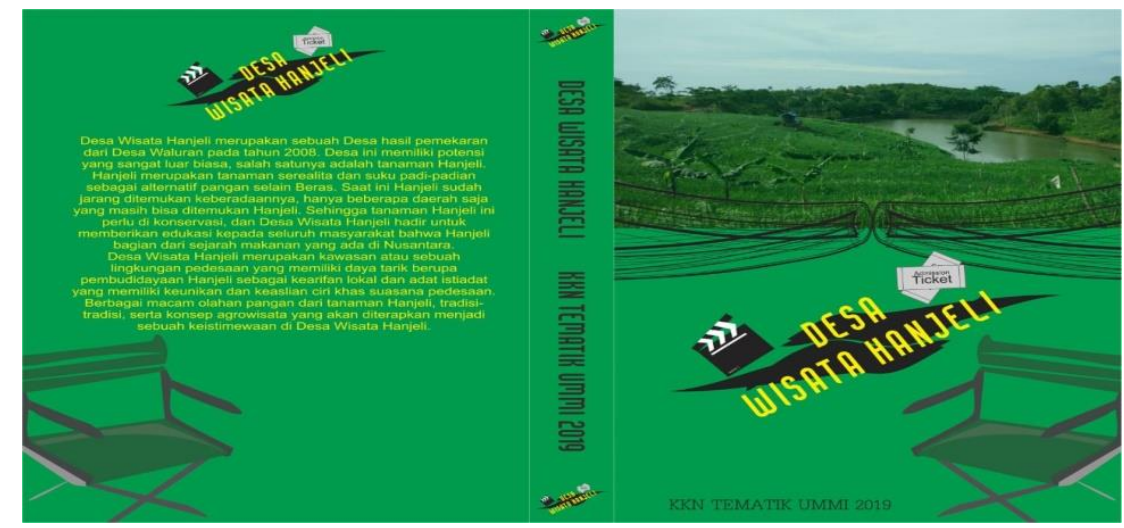

Gambar 10. Cover Buku Desa Wisata Hanjeli 
Tujuan dari buku desa Wisata Hanjeli ini adalah guna menunjang bagi para pengunjung Edu Wisata Hanjeli lebih dalam mengenal Desa Wisata Hanjeli ini. Sedangkan penyusunan buku ini menggunakan metode penelitian kualitatif, dimana penelitian ini adalah penelitian tentang riset yang bersifat deskriptif dan cenderung menggunakan analisis, landasan teori di manfaatkan sebagai pemandu agar fokus penelitian sesuai dengan fakta di lapangan.

Selanjutnya hasil penyusunan dari buku ini diserahkan kepada pihak editor untuk diperbaiki kembali dan dicetak untuk dijadikan buku karya Mahasiswa KKN Tematik UMMI Program URIMASTU 2019. Hasil buku tersebut akan dicetak sebanyak 25 pcs dengan rincian pembagian 15 kepada peserta KKN sisanya dibagikan kepada pihak Desa Waluran Mandiri, Perpustakaan UMMI, Desa Wisata Hanjeli dan lain-lain.

\section{KESIMPULAN}

Setelah dilaksanakannya kegiatan pengabdian pada masyarakat di Desa Waluran Mandiri Kecamatan Waluran Kabupaten Sukabumi, maka kami dapat menyimpulkan sebagai berikut.

1. Perguruan tinggi dengan melakukan pengabdian masyarakat ini melalui program KKN menjadikan sarana untuk mengaplikasikan ilmu pengetahuan yang telah diperoleh mahasiswa dari di bangku kuliah secara teori di kampus Universitas Muhammadiyah Sukabumi. Hal tersebut merupakan sebuah wujud nyata dalam pengalaman yang bermakna bagi mahasiswa dalam kehidupan masyarakat secara langsung.

2. Masyarakat sangat mendukung dengan kehadiran mahasiswa $\mathrm{KKN}$ serta turut membantu dalam pelaksanaan program-program yang disusun dan dilaksanakan dalam rangka pengembangan Desa Wisata Hanjeli, sehingga dapat terbentuklah kelompok kerja usaha dengan merintis sebuah usaha Edu Wisata Hanjeli dengan melibatkan para masyarakat tuna karya.

3. Dengan adanya kegiatan pengabdian ini maka dapat dijadikan salah satu cara untuk dapat menuntaskan kemiskinan bagi warga masyarakat desa Waluran Mandiri, melalui program usaha Edu Wisata Hanjeli yang mengembangkan keahlian para warga masyarakat dengan mengelola sumber daya alam yang sangat berpotensi untuk mensejahterakan warganya.

\section{DAFTAR PUSTAKA}

Badan Pusat Statistik. 2018. Kabupaten Sukabumi Dalam Angka 2018. Sukabumi: BPS Kabupaten Sukabumi.

BPS. 2018. Keadaan Ketenagakerjaan Indonesia Agustus 2018. Jakarta: Badan Pusat Statistik.

Karyaone. 2019. Cara Mengatasi Pengangguran yang Efektif di Indonesia.

Nurulliah, N. 2019. Angka Pengangguran di Jabar Ditargetkan Turun 1 Persen pada 
2023.

Prevention, U., Taruna, K., \& Taruna, E. 2007. Efektivitas program penanggulangan pengangguran karang taruna "eka taruna bhakti" desa sumerta kelod kecamatan denpasar timur kota denpasar, 2.

Ramdan, E. al. 2019. Pedoman Kegiatan KKN Tematik Universitas Muhammadiyah Sukabumi. Sukabumi: LPPM UMMI:Universitas Muhammadiyah.

Widodo, S., \& Nugroho, T. R. D. A. 2014. Model Pendidikan Kewirausahaan Bagi Santri Untuk Mengatasi Pengangguran di Pedesaan, 30(2). 
Volume 4, Nomor 2, September 2020 